\title{
DEVELOPMENT OF AN INTEGRATED BIM AND LEAN MATURITY MODEL
}

\author{
Sajedeh Mollasalehi ${ }^{1}$, Ahmed Adel Aboumoemen², Anushka Rathnayake ${ }^{3}$, Andrew \\ Fleming ${ }^{4}$, Jason Underwood ${ }^{5}$
}

\begin{abstract}
The level of Building Information Modelling (BIM) and Lean adoption has been rapidly increased. The benefits of integrating these two approaches have also been identified. However, to achieve the maximum benefits of the interaction of these two approaches, there needs to be assessment tools to analyse their performances collectively. Because understanding and analysing the performances of these approaches would provide value to the entire project in terms of lessons learned, more value generation, and continuous improvements. Therefore, this paper aims to propose an integrated BIM and Lean Maturity Model based on reviewing the literature around current maturity models.

This paper proposes an Integrated BIM and Lean Maturity Model named "IDEAL" which could serve as a basis in terms of assessing the performances of the projects implementing BIM and Lean together.
\end{abstract}

\section{KEYWORDS}

Maturity Models, Maturity Assessments, Lean Construction, Building Information Modelling (BIM)

\subsection{INTRODUCTION}

In recent years, the application of new innovative and technological approaches has been increased to improve overall project productivity and performances within the construction industry. The most beneficial approaches can be considered to be BIM and Lean Construction which provide benefits to the construction industry. Because of the increased adoption of BIM and Lean approaches, there is a need of having proper assessment tools or models to analyse the performances of these approaches.

\footnotetext{
PhD Candidate, University of Salford, UK, s.mollasalehi1@edu.salford.ac.ukAnon

PhD Candidate, University of Salford, UK, a.a.aboumoemen@edu.salford.ac.uk

PhD Candidate, University of Salford, UK, prasadini88salford@ gmail.com

Senior Lecturer, School of the Built Environment, University of Salford, UK, a.j.fleming@salford.ac.uk

5 Professor, School of the Built Environment, University of Salford, UK, j.underwood@salford.ac.uk
} 
Sajedeh Mollasalehi, Ahmed Adel Aboumoemen, Anushka Rathnayake, Andrew Fleming, Jason Underwood

There are different assessment tools and maturity models available for assessing the performances of BIM and Lean individually. However, due to the increased adoption of these two approaches together, there is a need of having an integrated maturity model or assessment tool to analyse the performance of both BIM and Lean together. Providing an integrated BIM and Lean maturity model would enhance analysing the performances of these two collectively together so that subsequently it would enable realising the benefits of both approaches.

\subsection{MATURITY ASSESSMENTS}

Over the recent years, an interest over maturity models have increased in such way that maintaining a maturity model supports organisations in becoming more mature (Khoshgoftar and Osman, 2009). Andersen and Jessen (2003) definition of maturity is the quality or state of being mature. Jugdev and Thomas (2002) pointed out that the main advantages of a maturity model is that it allows to recognize strengths, weaknesses, and benchmarking information for projects and organisations. However, maturity models also possesses a set of limitations, from a theoretical perspective in specific (Dakhil and Alshawi, 2014; Jugdev and Thomas, 2002). Existing literature shows that a set of maturity models have been used to assess organisations (Khoshgoftar and Osman, 2009). The Software Engineering Institute (SEI) developed the CMM, which is based on a software development process (SEI, 1993). Six models have been created from this development, but lately it has been integrated into a holistic maturity model that has been named by the CMMI. This Model includes 5 levels of maturities which are explained in Table 1 (SEI. 1993).

Table 1: The Software Engineering Institute CMM defined (SEI. 1993)

\begin{tabular}{cl}
\hline Maturity level & \multicolumn{1}{c}{ Definition } \\
\hline Initial / Ad-hoc & $\begin{array}{l}\text { Processes are usually ad hoc and the organization usually does not } \\
\text { provide a stable environment. Organizations are characterized by a } \\
\text { tendency to over commit, abandon processes in the time of crisis, and } \\
\text { not able to repeat their past successes again. } \\
\text { Deftware development successes are repeatable. The processes may } \\
\text { not repeat for all the projects in the organization. }\end{array}$ \\
Managed & $\begin{array}{l}\text { The organization's set of standard processes is established and } \\
\text { improved over time. These standard processes are used to establish } \\
\text { consistency across the organisation. }\end{array}$ \\
Integrated & $\begin{array}{l}\text { Using precise measurements, management can effectively control the } \\
\text { software development effort. At this level, organisation set a quantitative } \\
\text { quality goal for both software process and software maintenance. }\end{array}$ \\
Optimised & $\begin{array}{l}\text { Focusing on continually improving process performance through both } \\
\text { incremental and innovative technological improvements. }\end{array}$ \\
\hline
\end{tabular}

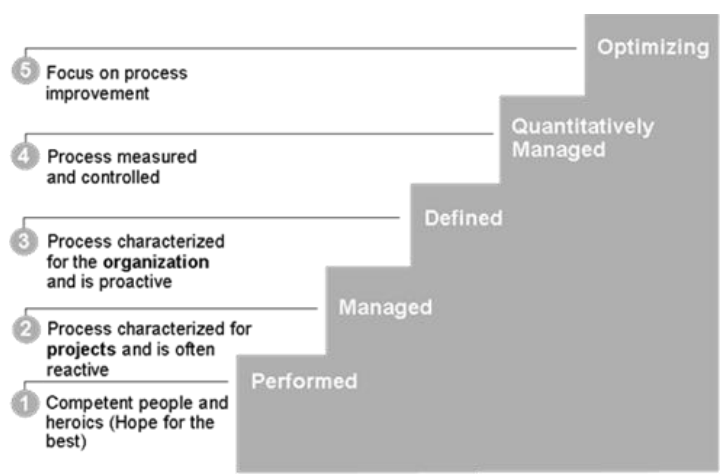


Figure 1- Capability Maturity Model Integration (CMMI) (Chrissis et al., 2003)

There is a need of having an integrated maturity model or assessment tool to analyse the performance of both BIM and Lean approaches together. Since most of the existing maturity models in relation to BIM and Lean have adopted the Capability Maturity Model Integration (CMMI) approach, therefore, CMMI should also be adopted when introducing the integrated BIM and Lean maturity model (Chrissis et al., 2003). Based on the CMM levels, an evolution of a maturity model was developed which includes 5 levels as explained in Figure 1 (Chrissis et al., 2003). By reviewing literature, the authors have selected only a few BIM and Lean maturity models which are most relevant to the context of this study.

\subsection{BIM MATURITIES}

According to Eastman et al. (2011, p.16) "BIM is a fundamentally different way of creating, using, and sharing building information lifecycle data". BIM provides many benefits to the whole projects lifecycle as "BIM facilitates a more integrated design and construction process" and thus this "results in better quality buildings at lower cost and reduced project duration" (Eastman et al., 2011).

Even though, BIM provides many benefits, to gain the true benefits of its adoption, individuals along with organizations should have the right knowledge to first use it and then to assess their performance of its usage (Smits et al., 2016). Additionally, due to different size and/or project types of companies, the BIM implementation level in organisations vary from one to another. Therefore, organisations need to consider the importance of adopting BIM maturity models and assessments based on the current available BIM maturity assessments (Chen et al., 2014; Succar, 2009).

There are many different BIM Maturities. Nevertheless, Most of the current BIM maturities follow the CMMI, since it is more relevant and related to the background of BIM than rest of the maturity types (Aboumoemen \& Underwood, 2017, Dakhil \& Alshawi, 2014). Bilal Succar (2010) defines BIM maturity as a state of the quality, repeatability and degree of excellence of a BIM model within a BIM capability. Succar developed a ranking system, namely Building Information Modelling Maturity (BIMM) that incorporates the essential parts for delivering BIM applications through an operational process. Several models have been developed by Industry practitioners and academics to assess construction industry's BIM performance and implementations (Giel and Issa, 2013; Nepal et al., 2014; Succar, 2010). BIM maturities are developed to measure efficiency of BIM competencies and capabilities across a set of construction industries (Aboumoemen \& Underwood, 2017).

A discussion on a selection of BIM maturity assessments is presented in this section. Since there has been a vast variety of BIM maturity assessments, the researchers have selected the two main ones that are more relevant in the context of this paper. 
Sajedeh Mollasalehi, Ahmed Adel Aboumoemen, Anushka Rathnayake, Andrew Fleming, Jason Underwood

\subsubsection{Bilal Succar BIM Maturity Matrix Index}

The BIM Maturity Matrix Index- (BIMMI) has been developed by Succar (2009) that is driven from the CMM. BIM framework components are combined on an information tool through performance improvement measurements, which justifies reason for development of the BIMMI. BIM Maturity levels can be demonstrated from Figure 2 below.

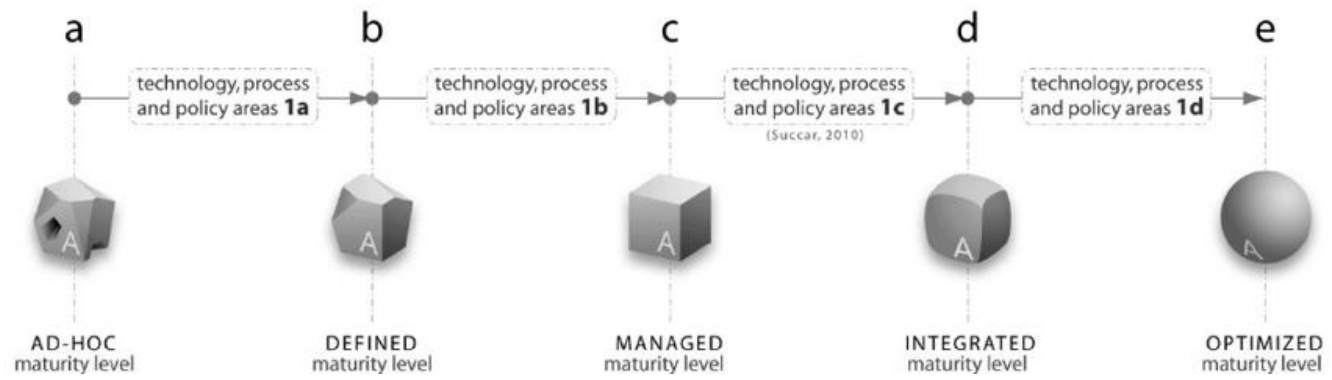

Figure 2 - The Five Maturity Levels (Succar, 2009)

\subsubsection{The U.S National Institute of Building Sciences BIM Model (NIBS)}

The U.S National Institute of Building Sciences (NIBS) developed the interactive BIM standard Capability Maturity Model (CMM), which incorporates areas of a BIM model such as Data richness, and the information related to its area of interest. A weighting importance is provided to each area of interest to distinguish them, which are classified consequently. A description of the maturity level is given to understand what they mean so the users expected to complete the assessment are to select the necessary levels, and then a score is given to each interest area that adds up to deliver the total sum of the maturity level. A certification level is demonstrated and points required to be achieved is displayed which allows organisations to see which maturity levels they fall under, where if it did not reach the minimum level, then how many points are required to reach the required level (NIBS. 2007) as shown in Figure 3.

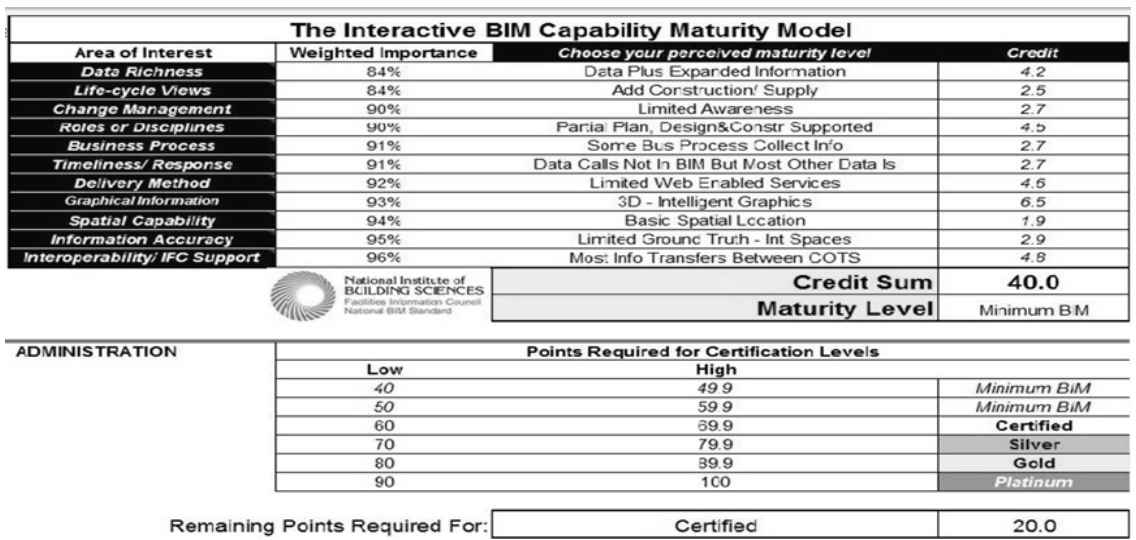

Figure 3 - Relation of Interactive model, and points required (NIBS. 2007) 


\subsection{LEAN MATURITY}

In the past 20 years, the construction industry has recognised the importance of adopting new approaches and principles to reduce waste and thus improve overall project productivity and performances (Egan, 1998; Latham 1994). Lean construction is recognised as one of the key approaches to improve the construction productivity by reducing waste (Egan, 1998; Mollasalehi et al., 2016). It was stated by Lehman \& Reiser (2004) "lean construction is a project delivery system based on Lean Production Management process, which is aimed at improving value by satisfying customer needs and improving performance". However, to understand the potential benefits of Lean and to achieve its true value, organisations need to measure and assess their lean implementation performances. This could be done through Lean maturity assessments and models. In recent years there is an increased level of interest in lean maturity models (Becker, et al., 2010). Lean Maturity models aim to manage the major revolution changes by defining directions, prioritising improvement opportunities, and guide cultural changes (Nesensohn, et al., 2014). Based on the review of Lean maturity assessments by Urban (2015), there are different types of Lean maturity assessments which adopt different approaches to assessing Lean maturity. These studies include: Lean Enterprise SelfAssessment Tool (LESAT) by Nightingale \& Mize (2002), Lean Production check-list by Sánchez \& Pérez (2001), Lean Construction Maturity Model (LCMM) by Nesensohn et al. (2014), Lean Manufacturing Performance Evaluation Audit by Donovan (2015), and Lean Index by Ray et al. (2006). Based on the above mentioned studies, two Lean Maturity assessments have been chosen in this paper which are most relevant in this context.

\subsubsection{Lean Enterprise Self-Assessment Tool (LESAT)}

Massachusetts Institute of Technology (MIT) assessment tool is one of the broadest system in business level invented by "Lean Aerospace Initiative" (Nightingale \& Mize, 2002). As a supporter for MIT assessment tool, Enterprise Level Roadmap as shown in Figure 4, was developed to complete overall process of lean implementation. Entry/Reentry cycle, Long Term cycle, and Short Term cycle are the main activities in the transition road map which support lean transformation.

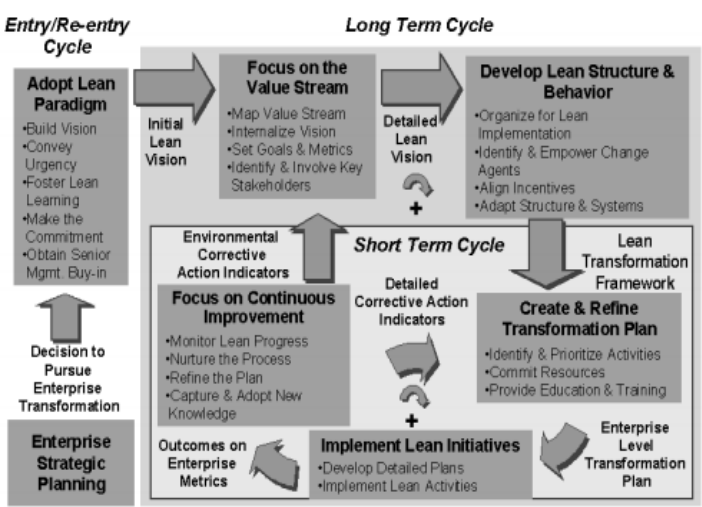

Figure 4 - Enterprise Level Transition to Lean Roadmap (Nightingale \& Mize, 2002), 
Sajedeh Mollasalehi, Ahmed Adel Aboumoemen, Anushka Rathnayake, Andrew Fleming, Jason Underwood

To complete the model, LESAT was proposed by LAI to support the model. There were five maturity statements in the LESAT Maturity, ranging from least capable (Level 1) to world-class (Level 5) (Nightingale \& Mize, 2002). Main characteristics of each level has been described in Table 2 below.

Table 2 - LESAT defined (Nightingale \& Mize, 2002)

\begin{tabular}{|c|c|}
\hline Maturity level & Definition \\
\hline Level 1 & $\begin{array}{l}\text { Some awareness of this practice; sporadic improvement activities may be } \\
\text { underway in a few areas }\end{array}$ \\
\hline Level 2 & $\begin{array}{l}\text { General awareness; informal approach deployed in a few areas with } \\
\text { varying degrees of effectiveness and sustainment. }\end{array}$ \\
\hline Level 3 & $\begin{array}{l}\text { A systematic approach/methodology deployed in varying stages across } \\
\text { most areas; facilitated with metrics; good sustainment. }\end{array}$ \\
\hline Level 4 & $\begin{array}{l}\text { On-going refinement and continuous improvement across the enterprise; } \\
\text { improvement gains are sustained. }\end{array}$ \\
\hline Level 5 & $\begin{array}{l}\text { Exceptional, well-defined, innovative approach is fully deployed across the } \\
\text { extended enterprise (across internal and external value streams); } \\
\text { recognized as best practice. }\end{array}$ \\
\hline
\end{tabular}

Although there are several models available for lean management, the completed model is developed by Lean Aerospace Initiative (LAI) which clearly defines principal activities and leading tasks as well as helpful enablers and instruments. The analysis of Hallam (2003) indicated that, thirty-one UK and USA industries have implemented LESAT. LESAT helps them to determine the current status of lean through an assessment process. However, like most of other available lean models, LAI's assessment relies on internal and external relations and strategic issues from the enterprise perspectives. A template of LESAT Maturity matrix is shown in Figure 5.

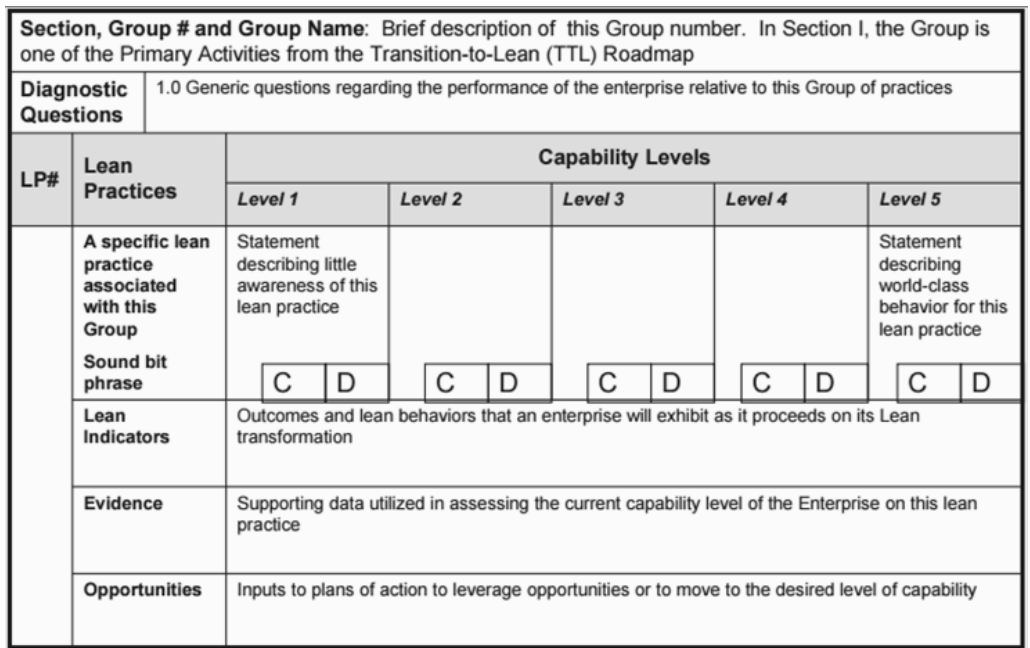

Figure 5 - LESAT Maturity Matrix Template

\subsubsection{Lean Construction Maturity Model}

Lean Construction Maturity Model (LCMM) was developed based on the CMMI model and its maturity levels. So, it comprises of five levels of maturity, 11 key Attributes, ad 
60 defined Behaviours, Goals \& Practices with 75 Ideal Statements to measure the maturity within organisations, which would provide essential support and guidance to the lean adoption in organisations (Nesensohn et al., 2014). Five maturity levels that are shown in Figure 6 measure the deviation between the Ideal Statement and the current state of the assessed organisation (Nesensohn et al., 2014). Each maturity level is defined in Table --- which are used to assess the project.

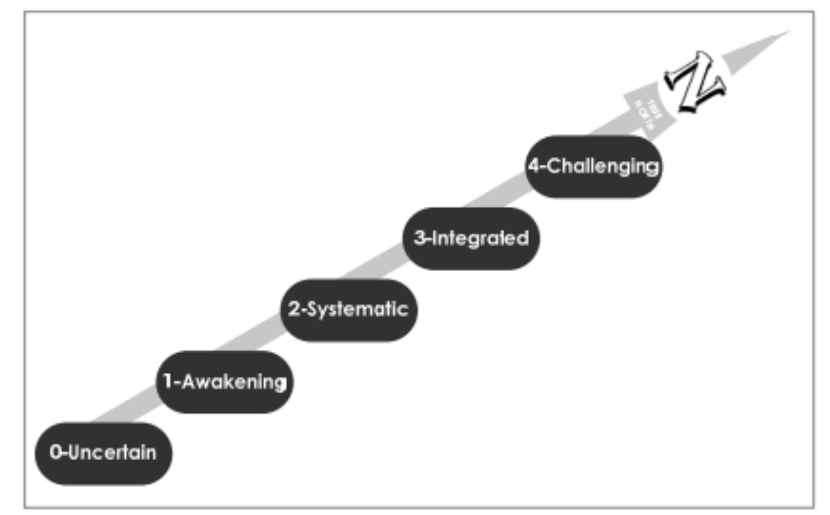

Figure 6 - Maturity Levels of the LCMM

Table 3 - Definition of the Maturity Levels

\begin{tabular}{cc}
\hline Maturity level & Definition \\
\hline $\begin{array}{c}\text { 0-Uncertain } \\
\text { 1-Awakening }\end{array}$ & $\begin{array}{c}\text { The Ideal Statement is hardly evidenced in action } \\
\text { General awareness exists and the Ideal Statement is } \\
\text { inconsistently evidenced in action }\end{array}$ \\
$\begin{array}{c}\text { 2-Systematic } \\
\text { 3-Integrated }\end{array}$ & $\begin{array}{c}\text { The Ideal Statement is systemically evidenced in action } \\
\text { T-Challenging }\end{array}$ \\
& The Ideal Statement is status quo which is challenged to \\
improve further
\end{tabular}

\subsection{AN INTEGRATED BIM AND LEAN MATURITY MODEL (IDEAL)}

BIM and Lean approaches provide many benefits to projects in many different ways when impalement individually. However, the integration of these two approaches would maximise the benefits and will result in better overall productivity and performance improvements (Mollasalehi et al., 2016). As the construction industry is realising the benefits of the interactions between these two approaches, there is an increased level of adoption of these approaches together (Mollasalehi et al., 2016; Sacks et al., 2010). Therefore, there needs to be an integrated maturity model to assess the level of BIM and Lean performances in projects that these two approaches have been implemented together. This paper proposes an integrated BIM and Lean Maturity Model which includes five main stages as shown in Figure 7. This model is based on critical reviewing of BIM and Lean maturity models which have been discussed in previous chapters. At each stage of this maturity model, the maturity levels of BIM, Lean and integrated BIM and Lean are defined. This integrated BIM and Lean Maturity Model which is called "IDEAL" Maturity Model, not only considers the level of BIM and Lean maturities individually, 
Sajedeh Mollasalehi, Ahmed Adel Aboumoemen, Anushka Rathnayake, Andrew Fleming, Jason Underwood

but it also considers the maturity level of these approaches collectively together. Firstly, by reviewing BIM and Lean maturity models separately, the authors extracted the main features and beneficial aspects of each model. Then, based on the findings from reviewing the maturity models and also the interaction between BIM and Lean approaches, the IDEAL model was developed. Each level in the IDEAL maturity model is described and defined in detail in relation to Figure 5 which can be demonstrated from Table 4. This IDEAL maturity model would enhance analysis of the projects' performances where BIM and Lean approaches are implemented together. Therefore, the performance of these two approaches would be analysed and assessed to better realisation of their benefits.

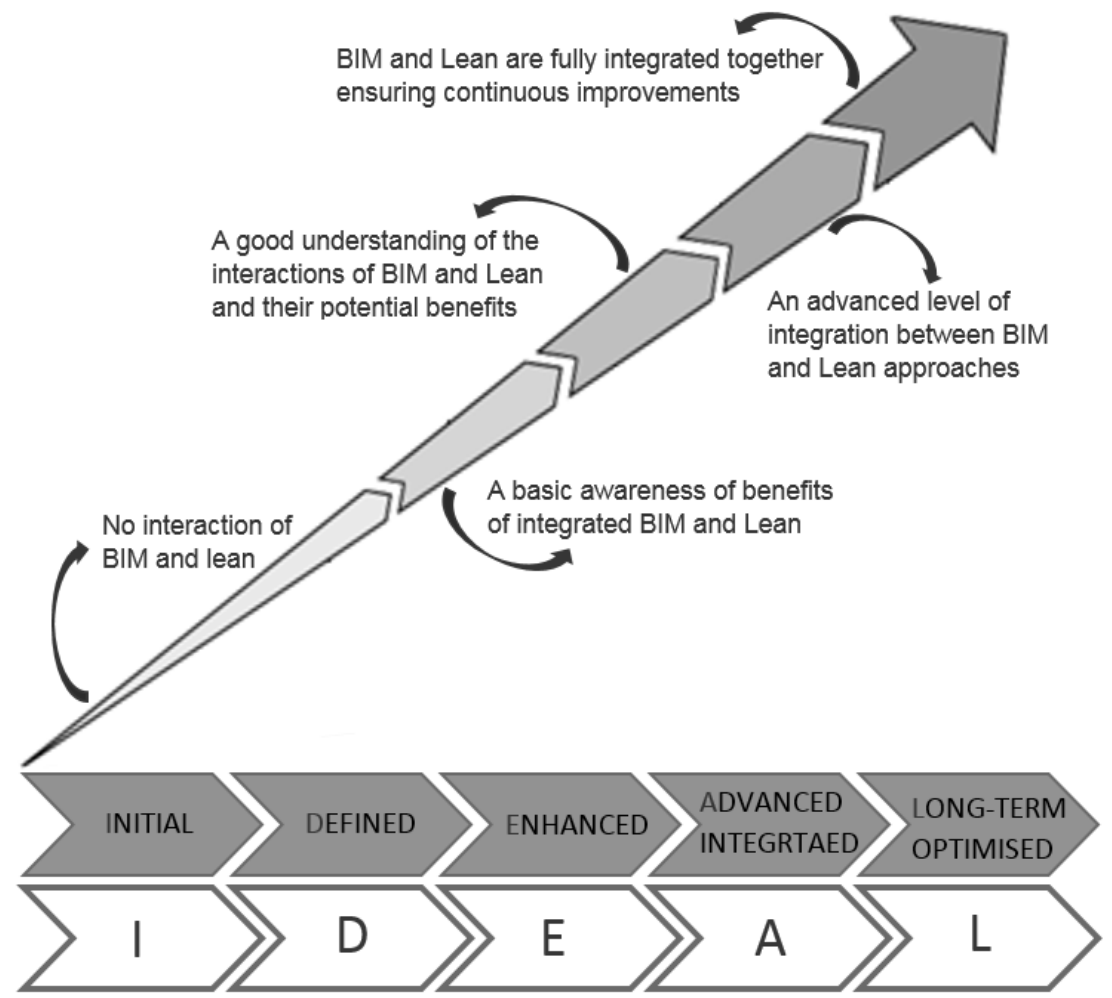

Figure 7 - IDEAL Maturity Model 
Table 4 - Definition of the suggested IDEAL Maturity Level

\begin{tabular}{|c|c|c|}
\hline $\begin{array}{l}\text { Maturity } \\
\text { Level }\end{array}$ & Approach & Description \\
\hline & $\begin{array}{l}\text { Tr } \\
\text { im } \\
\text { co } \\
\text { fu } \\
\text { co }\end{array}$ & $\begin{array}{l}\text { There is not a defined systematic processes and policies in terms of BIM } \\
\text { mplementation. Therefore, BIM is not fully implemented and there is a lack of } \\
\text { consistent support from the management team. Also, the use of software is not } \\
\text { ully systematic and embedded amongst team members. Thus, there is no true } \\
\text { collaboration between project members. }\end{array}$ \\
\hline \multirow[t]{2}{*}{ Initial } & Lean & $\begin{array}{l}\text { There is some awareness of few lean practices or tools, but lean is not fully } \\
\text { mplemented. The philosophy of lean thinking is not well understood and adopted. } \\
\text { Therefore, some activities in terms of lean adoption may be underway in a few } \\
\text { areas but not to the full extent. }\end{array}$ \\
\hline & $\begin{array}{l}\text { ntegrated } \\
\text { BIM and } \\
\text { Lean }\end{array}$ & $\begin{array}{l}\text { As BIM and Lean approaches are not fully implemented, the potential benefits of } \\
\text { nteraction of BIM and lean are not recognised and fully understood. Even though, } \\
\text { here might be few BIM and Lean activities undertaken, but they are not in line. }\end{array}$ \\
\hline \multirow[t]{2}{*}{$\begin{array}{l}\text { Maturity } \\
\text { Level }\end{array}$} & Approach & Description \\
\hline & $\begin{array}{l}\text { Th } \\
\text { tru } \\
\text { do } \\
\text { co } \\
\text { to } \\
\text { BI }\end{array}$ & $\begin{array}{l}\text { The management team is driving the BIM implementation but there is still a lack of } \\
\text { rue BIM knowledge, BIM software skills, and true mind-set. There are basic } \\
\text { documentation of processes and policies, but due to lack of fully effective } \\
\text { collaborative environment, BIM is not fully adopted. However, there is initial steps } \\
\text { owards mutual trust/respect among project participants which intends to follow the } \\
\text { BIM processes }\end{array}$ \\
\hline \multirow[t]{2}{*}{ Defined } & Lean & $\begin{array}{l}\text { There is a general awareness in terms of Lean practices. Some informal } \\
\text { ppproaches deployed in a few areas and some of the Lean tools are used. }\end{array}$ \\
\hline & $\begin{array}{l}\text { ntegrated } \\
\text { BIM and } \\
\text { Lean }\end{array}$ & $\begin{array}{l}\text { As BIM and Lean approaches are not fully implemented, the potential benefits of } \\
\text { nteraction of BIM and lean are not recognised and fully understood. Even though, } \\
\text { here might be few BIM and Lean activities undertaken, but they are not in line. }\end{array}$ \\
\hline \multirow[t]{2}{*}{$\begin{array}{l}\text { Maturity } \\
\text { Level }\end{array}$} & Approach & Description \\
\hline & BIM & $\begin{array}{l}\text { There is a well understanding of BIM implementation vision by the majority of } \\
\text { project participants. There is a BIM implementation strategy which is linked with } \\
\text { the action planned that are in details. BIM is acknowledged not only as a tool, } \\
\text { but a combination of technology, process, and people. Therefore, there is an } \\
\text { advanced level of collaboration amongst project members. }\end{array}$ \\
\hline \multirow[t]{2}{*}{ Enhanced } & Lean & $\begin{array}{l}\text { There is a systematic approach of Lean implementation in varying stages across } \\
\text { most areas. The philosophy of Lean thinking is well understood and the lean } \\
\text { principles and tools are being adopted within the projects. }\end{array}$ \\
\hline & $\begin{array}{l}\text { Integrated } \\
\text { BIM and } \\
\text { Lean }\end{array}$ & $\begin{array}{l}\text { There is a good understanding of the interactions of BIM and Lean and their } \\
\text { potential benefits. Some of the adopted BIM features are in line with the Lean } \\
\text { principles to achieve the benefits of integrated BIM and Lean. For example, Last } \\
\text { Planner System (LPS), as one of the lean tools, is implemented in line with BIM } \\
\text { features, such as visualisation and collaboration. }\end{array}$ \\
\hline \multirow[t]{2}{*}{$\begin{array}{l}\text { Maturity } \\
\text { Level }\end{array}$} & Approach & Description \\
\hline & BIM & $\begin{array}{l}\text { The requirements and processes of BIM implementation are fully integrated into } \\
\text { organisational, strategic, managerial and communicative channels. Modelling } \\
\text { deliverables are well synchronized across projects and tightly integrated with } \\
\text { business processes. BIM standards and performance benchmarks are } \\
\text { incorporated into quality management and performance improvement systems. } \\
\text { Therefore, Productivity is now consistent and predictable in the BIM collaborative } \\
\text { environment. }\end{array}$ \\
\hline \multirow[t]{2}{*}{$\begin{array}{l}\text { Advanced } \\
\text { Integrated }\end{array}$} & Lean & $\begin{array}{l}\text { Lean is fully implemented and there is on-going continuous improvements across } \\
\text { projects. The philosophy of Lean thinking is fully understood and the Lean } \\
\text { principles and tools are fully practiced towards continuous improvements. }\end{array}$ \\
\hline & $\begin{array}{l}\text { Integrated } \\
\text { BIM and } \\
\text { Lean }\end{array}$ & $\begin{array}{l}\text { There is an advanced level of integration between BIM and Lean approaches. } \\
\text { These approaches are working in parallel and towards same goals. So the } \\
\text { interaction of BIM features with Lean principles are fully understood and the BIM } \\
\text { and Lean implementation is practiced in line with those interactions. }\end{array}$ \\
\hline \multirow[t]{2}{*}{$\begin{array}{l}\text { Maturity } \\
\text { Level }\end{array}$} & Approach & Description \\
\hline & BIM & $\begin{array}{l}\text { BIM vision is actively achieved. The implementation of BIM strategy and its } \\
\text { effects on organisational models are continuously revisited and realigned } \\
\text { with other strategies. Selection/use of software tools is continuously revisited } \\
\text { to enhance productivity and align with strategic objectives. Collaborative } \\
\text { responsibilities, risks and rewards are continuously revisited and realigned. } \\
\text { Benchmarks are repetitively revisited to insure highest possible quality in } \\
\text { processes, products and services. }\end{array}$ \\
\hline \multirow[t]{2}{*}{$\begin{array}{l}\text { Long-Term } \\
\text { Optimisation }\end{array}$} & Lean & $\begin{array}{l}\text { The lean philosophy is embedded within the organisational level and the lean } \\
\text { principles and tools are fully implemented. The lean practice is repetitively } \\
\text { revisited to insure highest possible quality in processes, products and } \\
\text { services. }\end{array}$ \\
\hline & $\begin{array}{l}\text { Integrated } \\
\text { BIM and } \\
\text { Lean }\end{array}$ & $\begin{array}{l}\text { BIM and Lean are fully integrated together towards achieving the highest } \\
\text { possible quality and productivity of the project and processes. Therefore, BIM } \\
\text { features are implemented fully in relation to Lean principles to ensure } \\
\text { continuous improvement of projects. }\end{array}$ \\
\hline
\end{tabular}


Sajedeh Mollasalehi, Ahmed Adel Aboumoemen, Anushka Rathnayake, Andrew Fleming,

\section{CONCLUSION}

It has been recognised that there is a need for an integrated BIM and Lean maturity model to assess the performances of projects that implement both BIM and Lean together. As the aim of this paper was to propose an integrated BIM and Lean maturity model, a review of the existing maturity models and assessments were conducted for BIM and Lean individually. Thus, this paper adopted some of the initial concepts of the current BIM and Lean maturity levels and then through looking at the interaction of the BIM and Lean, an integrated BIM and Lean maturity model was proposed.

This paper proposes a maturity model named "IDEAL" which aims to assess and analyse the performances of the projects that are implementing BIM and Lean together. This IDEAL model comprises of five main levels which are in line with the level of integration of BIM and Lean. Therefore, the performance of these two approaches could be analysed and assessed through this proposed model to better realisation of their benefits.

This paper proposes this model, but the next stage of this study is to then validate this proposed model in a real-life construction project. So, the authors of this paper would recommend the use of the IDEAL maturity model in construction projects to both validate the model and assess their performances in relation to the adoption of integrated BIM and Lean. Also, it is recommended to examine and investigate the usage of the IDEAL model amongst the projects to better identify its benefits.

\section{REFERENCES}

Aboumoemen, A. \& Underwood, J. (2017). A Level 2 BIM Maturity-KPI Assessment: Literature Review. 13th International Postgraduate Research Conference (IPGRC 2017), 14-15 September 2017, Salford, UK.

Andersen, E. S., \& Jessen, S. A. (2003). Project maturity in organisations. International Journal of Project Management, 21(6), 457-461. doi: 10.1016/S0263-7863(02)000881

Azhar, S. (2011). Building information modeling (BIM): Trends, benefits, risks, and challenges for the AEC industry. Leadership and management in engineering, 11(3), 241-252. doi: 10.1061/(ASCE)LM.1943-5630.0000127

Becker, J., Niehaves, B., Pöppelbuß, J. \& Alexander, S., 2010. Maturity Models in IS ResearcH. Pretoria., s.n.

Chen, Y., Dib, H., \& F. Cox, R. (2014). A measurement model of building information modelling maturity. Construction Innovation, 14(2), 186-209.

Chrissis, M. B., Konrad, M., \& Shrum, S. (2003). CMMI guidelines for process integration and product improvement: Longman Publishing Co., Inc.

Dakhil, A., \& Alshawi, M. (2014). BIM Benefits-Maturity Relationship from Client Perspective. Information and Knowledge Management, 4(9), 8-16.

Eastman, C., Teicholz, P., Sacks, R. \& Liston, K. (2011). BIM handbook: A guide to building information modeling for owners, managers, designers, engineers, and contractors (2nd ed.). Hoboken, N.J.: John Wiley \& Sons. 
Egan, J. (1998). Rethinking Construction. Construction Task Force Report for Department of the Environment, Transport and the Regions. DETR, London.

Giel, B., \& Issa, R. R. (2013). Synthesis of existing BIM maturity toolsets to evaluate building owners. Computing in Civil Engineering, 451-458. doi: 10.1061/9780784413029.057

Hallam, C. R. A., 2003. Lean enterprise self-assessment as a leading indicator for accelerating transformation in the aerospace industry. MIT, USA.

Jugdev, K., \& Thomas, J. (2002). Project management maturity models: The silver bullets of competitive advantage. Project Management Institute, Project Management Journal, 33(4), 4-14.

Khoshgoftar, M., \& Osman, O. (2009). Comparison of Maturity Models School of Housing, Building and Planning. Computer Science and Information Technology. 2nd IEEE International Conference, 297-301. doi:10.1109/ICCSIT.2009.5234402

Latham, S. M. (1994). Constructing the team.

Lehman, T., \& Reiser, P. (2004). Maximizing Value \& Minimizing Waste-Value Engineering \& Lean Construction. In Proceedings of SAVE International Conference, USA.

LESAT, 2001. Lean Enterprise Self-Assessment Tool - Facilitator's Guide. Lean Aerospace Initiative - Massachusetts Institute of Technology.

Mollasalehi, S., Fleming, A., Talebi, A., \& Underwood, J. (2016). Development of an Experimental Waste Framework Based on BIM/Lean Concept in Construction Design. In Proceedings of the 24th IGLC. Boston, USA.

Nepal, M. P., Jupp, J. R., \& Aibinu, A. A. (2014). Evaluations of BIM: frameworks and perspectives. Computing in Civil and Building Engineering (2014), 769-776. doi: 10.1061/9780784413616.096

Nesensohn, C., Bryde, D., Ochieng, E. \& Fearon, D., 2014. Maturity and Maturity Models in Lean Construction. Australasian Journal of Construction, 14(1), p 45-59.

NIBS. (2007). United States National BIM Standards Version 1 - Part 1: Overview, principles and Methodologies. Washington, DC.

Nightingale, D. J., \& Mize, J. H. (2002). Development of a lean enterprise transformation maturity model. Information Knowledge Systems Management, 3(1), 15-30.

Sacks, R., Koskela, L., Dave, B. A., and Owen, R. (2010). Interaction of lean and building information modeling in construction. Journal of construction engineering and management 136(9), 968-980.

SEI. (1993) Key Practices of the Capability Maturity Model, Version 1.1, Software Engineering Institute.

Succar, B. (2009). Building information modelling framework: a research and delivery foundation for industry stakeholders. Automation in Construction, 18(3), 357-375. doi:10.1016/j.autcon.2008.10.003

Succar, B. (2010). Building information modelling maturity matrix, in J. Underwood and U. Isikdag (eds.), Handbook of Research on BIM and Construction Informatics: Concepts and Technologies, Hershey, PA: IGI Global, pp. 65-103. 
Sajedeh Mollasalehi, Ahmed Adel Aboumoemen, Anushka Rathnayake, Andrew Fleming,

Jason Underwood

Succar, B. (2013). BIM: conceptual constructs and performance improvement tools. School of Architecture and Built Environment Faculty of Engineering and Built Environment University of Newcastle.

Smits, W., Buiten, V. M., \& Hartmann, T. (2016). Yield-to-BIM: impacts of BIM maturity on project performance. Building Research \& Information, 1-11. doi: $10.1080 / 09613218.2016 .1190579$

Urban, W. (2015). The lean management maturity self-assessment tool based on organizational culture diagnosis. Procedia-Social and Behavioral Sciences, 213, 728733. 